\title{
PEMILIHAN FONDASI CSTR UNTUK PRODUKSI BIOGAS DARI POME DALAM RANGKA MENINGKATKAN PENGEMBANGAN ENERGI TERBARUKAN
}

\section{Selection of a CSTR Foundation for Biogas Production from POME to Improve Renewable Energy Development}

\author{
Herman Hidayat ${ }^{1}$, Samdi Yarsono ${ }^{2)}$, Imaduddin $\mathrm{Haq}^{3)}$, Kornelis Kopong Ola ${ }^{4)}$, \\ Agus Hadi Santosa Wargadipura ${ }^{5)}$, Winda Wulandari", dan Bambang Muharto ${ }^{11}$ \\ ${ }^{1)}$ Pusat Teknologi Sumberdaya Energi dan Industri Kimia (PTSEIK), ${ }^{2}$ Balai Teknologi Bahan Bakar dan \\ Rekayasa Desain (BTB2RD), ${ }^{3}$ Pusat Teknologi Industri Permesinan (PTIM), ${ }^{4}$ Balai Besar Teknologi \\ Konversi Energi (B2TKE), ${ }^{5}$ Pusat Teknologi Material (PTM) \\ Badan Pengkajian dan Penerapan Teknologi (BPPT) \\ Gedung Energi 625 Kawasan PUSPIPTEK, Tangerang Selatan \\ Email: herman.hidayat@bppt.go.id
}

Diterima: 31 Agustus 2020; Diperiksa: 14 September 2020; Revisi: 9 November 2020; Disetujui: 3 Desember 2020

\begin{abstract}
Renewable energy development for power generation is in line with the government's program to increase the share of renewable energy in the national energy mix which is relatively small at the moment. BPPT, collaborating with PTPN 5 in the Insinas Flagship program, built a pilot plant for biogas production from Palm Oil Mill Effluent (POME) with a capacity of $700 \mathrm{~kW}$. The reactor used in this pilot project is a Continuous Stirred Tank Reactor (CSTR) which is the most important operating unit for producing biogas from POME. Therefore, the selection of the CSTR foundation is crucial since the main process occurs in the reactor. The scope of this activity is to realize the final design into the construction of a CSTR pilot plant. Several types of foundations were studied, starting from shallow foundation type such as tread foundation, deep foundation, until combining shallow foundation type with deep foundation type. The evaluation of existing data and design review indicates that the use of Mat Foundation is not suitable due to soil condition at a depth of $0-5 m$ which is in the form of sandy loam soil with an NSPT value of less than 20. The selection of Piles is based on the calculations using total vertical load of 3035,37 ton and total horizontal load of 542,57 tons. Considering the availability of materials and time concern, the recommended foundation type is pile with a diameter of $600 \mathrm{~mm}$ type $B$ and a length of $12 \mathrm{~m}$.
\end{abstract}

Keywords: CSTR foundation construction, Mat Foundation, pile foundation, pilot plant construction

\begin{abstract}
Abstrak
Pengembangan energi terbarukan untuk pembangkit listrik selaras dengan program pemerintah dalam meningkatkan perannya pada bauran energi (energy mix) nasional, dimana saat ini porsi dari sumber energi terbarukan masih relatif kecil. BPPT, bekerjasama dengan PTPN 5 dalam program Flagship Insinas, melakukan pembangunan pilot plant untuk produksi biogas dari Palm Oil Mill Effluent (POME) dengan kapasitas setara 700 kW. Reaktor yang digunakan dalam pilot project ini adalah Continuous Stirred Tank Reactor (CSTR) dan merupakan unit operasi yang paling penting untuk memproduksi biogas dari POME. Sehingga pemilihan fondasi CSTR krusial karena menunjang proses utama yang terjadi pada reaktor tersebut. Ruang lingkup dari kegiatan ini adalah merealisasikan hasil desain menjadi konstruksi pilot plant CSTR. Beberapa inovasi tipe fondasi dikaji, dimulai dari tipe fondasi dangkal (shallow foundation) seperti fondasi telapak sampai dengan fondasi dalam (deep foundation) atau melakukan kombinasi antara tipe fondasi dangkal dengan tipe fondasi dalam. Hasil evaluasi data yang ada serta design review menunjukkan bahwa penggunaan mat foundation tidaklah memungkinkan dikarenakan kondisi tanah pada kedalaman 0-5 m berupa tanah lumpur berpasir dengan nilai NSPT kurang dari 20. Pemilihan tiang pancang dilakukan berdasarkan perhitungan dengan basis beban pada arah vertikal sebesar 3035,37 ton dan beban pada arah horizontal sebesar 542,57 ton. Dengan mempertimbangkan ketersediaan bahan dan waktu, tipe fondasi yang direkomendasikan adalah tiang pancang (pile) dengan diameter $600 \mathrm{~mm}$ type B dan panjang $12 \mathrm{~m}$.
\end{abstract}

Kata kunci: fondasi tiang pancang, konstruksi fondasi CSTR, konstruksi pilot plant, mat foundation 


\section{PENDAHULUAN}

Industri kelapa sawit di Indonesia merupakan salah satu industri terbesar di dunia dengan tingkat produksi Crude Palm Oil (CPO) sebesar 35,36 juta ton pada tahun 2017. Pertumbuhan rata-rata selama periode 2016-2017 sebesar 10,84\% (Outlook Kelapa Sawit 2017). Produksi CPO tentunya diikuti oleh tingginya produksi limbah cair berupa Palm Oil Mill Effluent (POME) yang selalu dianggap sebagai air limbah yang banyak mengandung polutan. Di sisi lain, pemanfaatan kembali POME untuk menghasilkan energi terbarukan dalam skala komersial memiliki potensi besar. Proses anaerob digunakan secara luas dalam industri ini sebagai metode utama pengolahan POME. Biogas yang diproduksi dari pabrik kelapa sawit bisa mencapai $0,7-1 \mathrm{~m}^{3}$ per ton tandan buah segar (TBS) kelapa sawit (Rahayu, AS dkk., 2015).

Pemanfaatan POME menjadi energi ini sejalan dengan program pemerintah dalam Pemanfaatan Sumber Energi Terbarukan Untuk Penyediaan Tenaga Listrik (PERMEN ESDM No. 50/2017, 2017). Sehubungan dengan hal tersebut, BPPT bekerjasama dengan PT Perkebunan Nusantara V (PTPN 5) saat ini sedang membangun pilot project untuk produksi biogas dari POME di Pabrik Kelapa Sawit (PKS) Sei Pagar, Riau melalui program Flagship Insinas MENRISTEKDIKTI tahun 2018-2020.

Reaktor yang digunakan dalam pilot project ini adalah Continuous Stirred Tank Reactor (CSTR) karena berbagai kelebihannya seperti waktu tinggal yang singkat dan produksi gas metana yang tinggi. CSTR merupakan salah satu unit operasi yang paling krusial dalam produksi biogas karena proses konversi POME menjadi biogas terjadi dalam unit ini. Oleh sebab itu, pemilihan tipe fondasi yang digunakan untuk CSTR ini sangat penting.

Tujuan dari studi ini adalah melakukan kajian mengenai perbandingan fondasi yang dipilih antara fondasi rakit (Mat) dan fondasi tiang pancang (Pile) dari segi biaya dan waktu. Luaran yang ditargetkan adalah kajian teknis pemilihan tipe fondasi yang sesuai dengan kebutuhan dan kondisi di lapangan serta sesuai dengan SNI 1927:2012 mengenai Tata Cara Ketahanan Gempa untuk Struktur Bangunan Gedung dan Non Gedung.

\section{BAHAN DAN METODE}

Metodologi dan tahapan kegiatan yang dilakukan dalam studi kajian ini, meliputi:

- Melakukan studi literatur dan rencana desain.

- Pengumpulan data primer dan sekunder, yaitu berupa data vendor pile.

- Melakukan review atas analisis desain dan data soil test.

- Menyusun rekomendasi tipe fondasi yang dipilih.

\section{HASILDAN PEMBAHASAN}

\subsection{Fondasi Tapak (Mat Foundation)}

Tuntuk memberikan gambaran dan melakukan estimasi biaya yang diperlukan dalam pembangunan 1 (satu) unit fondasi bioreactor CSTR, dilakukan preliminary design tapak satu unit CSTR seperti dapat dilihat pada Gambar 1.

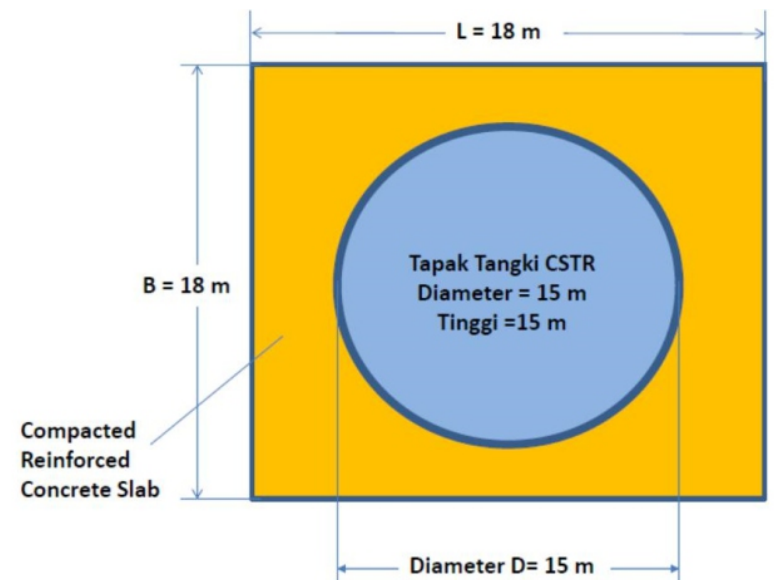

(a) Tapak Fondasi unit CSTR

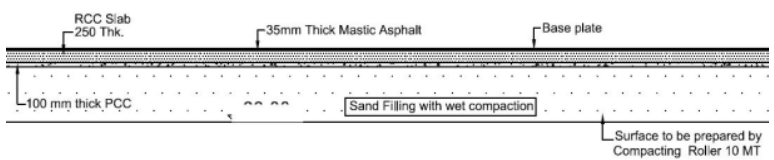

(b) Potongan Slab Beton RCC untuk menumpu unit Tangki CSTR

(c)

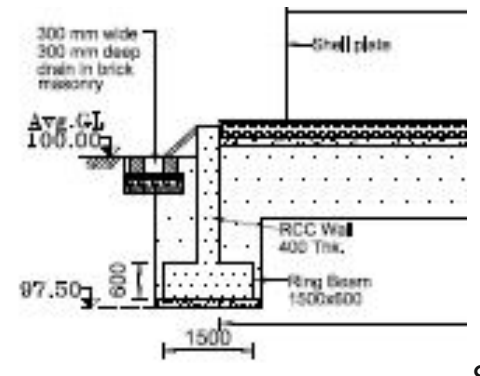

Beton RCC

Sekeliling Slab

\section{Gambar 1. Sistem Fondasi Bioreaktor CSTR}

Berat tangki CSTR berkapasitas $2000 \mathrm{~m}^{3}$ dan berat fluida POME di dalamnya memberikan beban sebesar 2155,4 ton pada fondasi. Untuk memperkecil kemungkinan tergesernya slab beton RCC, dibuat konstruksi fondasi telapak yang mengeliling slab beton tersebut seperti dapat dilihat pada Gambar 2. Berdasarkan Peraturan Beton Indonesia (PBI) 1971, mutu kuat beton yang digunakan adalah K-250 dengan mutu steel bar reinforcement yang memiliki Tegangan Luluh (Yield Stress $/ \sigma_{y}$ ) sebesar 41,50 MPa. Dimensi selimut beton (concrete cover) adalah $45 \mathrm{~mm}$ untuk dinding beton, $50 \mathrm{~mm}$ untuk fondasi dan 25 $\mathrm{mm}$ untuk slab beton bertulang. Selain itu, 
pendetailan penulangan dan pekerjaan beton dilakukan sesuai dengan persyaratan yang ditentukan dalam SNI 03 - 2847 - 2002: Tata Cara Perencanaan Struktur Beton untuk Bangunan

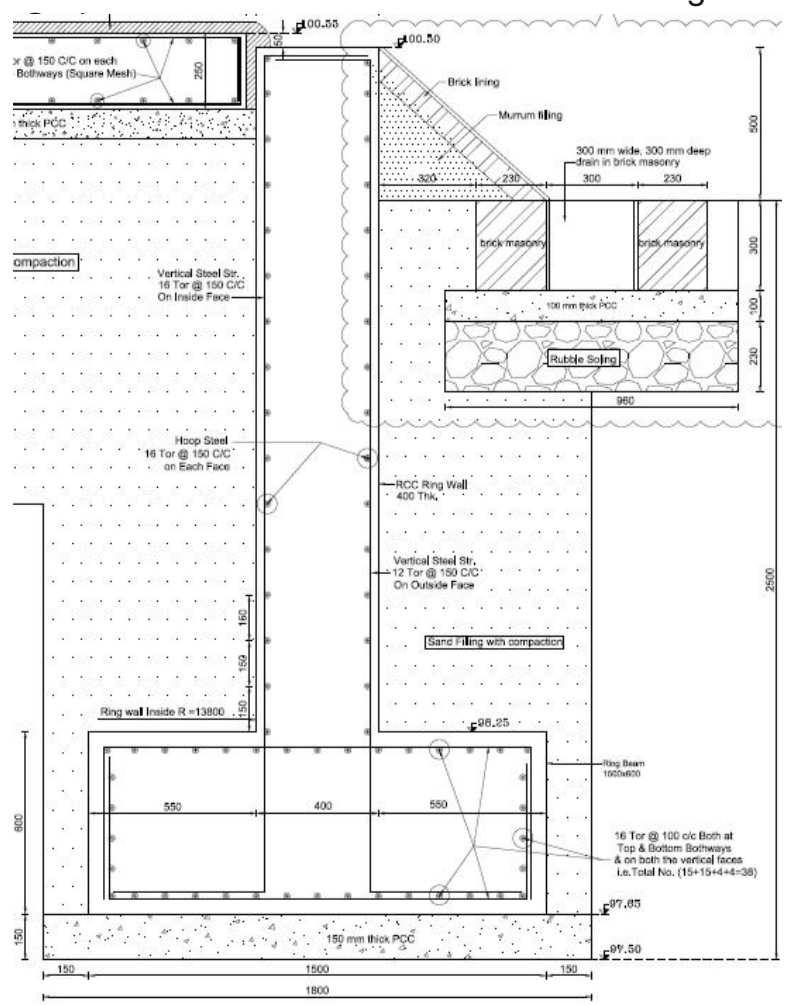

Gambar 2. Desain Fondasi Telapak Beton Bertulang sekeliling Slab Beton

\subsection{Bahan Campuran Beton}

\subsubsection{Semen Portland (Portland Cement - PC)}

Semua merek PC yang digunakan adalah portland cement merek Standard, yang telah disetujui oleh badan yang berwenang dan memenuhi persyaratan Portland Cement sesuai dengan SNI 15-2049-2004. Seluruh pekerjaan menggunakan satu merek PC. PC disimpan secara baik dan dihindarkan dari kelembaban sampai tiba saatnya untuk dipakai. PC yang telah menggumpal atau membatu tidak boleh digunakan. PC disimpan sedemikian rupa sehingga mudah untuk diperiksa dan diambil contohnya.

\subsubsection{Kerikil koral dan pasir (agregat kasar dan halus)}

Agregat yang digunakan sesuai dengan syaratsyarat PBI $1971 \mathrm{Bab} 3$ ayat 3.3, 3.4 dan 3.5. Agregat kasar berupa koral atau crushed stones yang mempunyai susunan gradasi yang baik, padat (tidak porous) dan cukup syarat kekerasannya. Agregat halus tidak boleh mengandung lumpur lebih dari 5\% (ditentukan terhadap berat kering).

Besar maksimum butir agregat kasar tidak boleh lebih dari $3,0 \mathrm{~cm}$ dan tidak lebih dari seperempat dimensi beton yang terkecil dari bagian konstruksi yang bersangkutan.

Agregat kasar dan halus diangkat dan disimpan terpisah untuk mencegah terjadinya segregasi berbagai ukuran partikel. Agregat harus dijaga terhadap kebersihan dan bebas terhadap materialmaterial lain. Kapasitas tempat harus disiapkan pada tempat sumbernya atau pada site untuk menjamin tersedianya kedua macam agregat tersebut dengan kualitas dan grading yang telah disetujui untuk menjamin kontinuitas pekerjaan.

\subsubsection{Air}

Air untuk pembuatan dan perawatan beton harus mengikuti syarat PBI 1971 pasal 3.6. Sebaiknya dipakai air bersih yang dapat diminum.

\subsubsection{Bahan pencampur (admixture)}

Admixture yang dicampurkan pada beton tidak diizinkan kecuali dengan persetujuan tertulis dari Pemberi Tugas/Pengawas Lapangan dan Perencana.

Untuk pemakaian admixture seperti di atas, kontraktor harus sudah membuat percobaanpercobaan perbandingan berat dan rasio W/C dari penambahan admixture tersebut. Hasil crushing test dilakukan terhadap kubus-kubus pada umur 7 , 14 dan 21 hari dari laboratorium.

\subsubsection{Desain Campuran Beton}

Adukan beton terdiri dari bahan semen, bahan pembantu (admixture), pasir, koral, dan air. Kualitas bahan tersebut memenuhi syarat PBI 1971.

Perbandingan campuran beton rencana untuk berbagai jenis pekerjaan beton ditentukan berdasarkan hasil percobaan kubus beton dan dapat dipakai untuk pekerjaan tersebut.

Bila kualitas campuran beton rencana yang telah disetujui diganti dari sumber ataupun agregatnya, maka dicari lagi campuran yang baru sehingga tetap memenuhi syarat. Untuk campuran beton yang baru tersebut prosedual membuat campuran testing kubus beton.

Di dalam PBI 1971, penentuan campuran beton, jumlah semen dan agregat akan diukur menurut berat kecuali dalam beberapa hal khusus. Pengukuran material dengan volume akan dipakai untuk bangunan-bangunan struktur yang kecil. Semua volume dan berat agregat, semen, dan air ditakar dengan seksama. Apabila proporsiproporsi yang disyaratkan tidak dilaksanakan, konstruksi beton yang sudah dicor akan diperintahkan untuk segera disingkirkan. Jumlah semen yang dipakai minimum sebesar $340 \mathrm{~kg} / \mathrm{m}^{3}$ beton untuk struktur bangunan air dan reservoir, serta minimum sebesar $275 \mathrm{~kg} / \mathrm{m}^{3}$ untuk struktur bangunan biasa.

\subsubsection{Persiapan Pengecoran Beton}

Sebelum pekerjaan beton dimulai, dibuat laporan tertulis 24 jam sebelumnya yang menyebutkan:

- Jumlah volume beton yang dicor

- Jumlah alat-alat pengecoran antara lain mixer, fibrator, yang tersedia di lapangan

- Jumlah portland cement yang tersedia di 
lapangan

- Jumlah pasir, koral/kerikil yang tersedia di lapangan

- Jumlah air yang tersedia untuk pembetonan

- Jumlah cetakan-cetakan kubus beton yang tersedia di lapangan

- Jumlah tenaga kerja yang ada di lapangan

- Perbandingan campuran beton yang akan dilaksanakan

- Time schedule pelaksanaan pengecoran

- Skema jalannya pengecoran sampai selesai

\subsubsection{Pencegahan Korosi}

Pipa, pipa listrik, angker, dan bahan lain yang terbuat dari besi yang ditanam dalam beton dipasang cukup kuat sebelum pelaksanaan pengecoran beton kecuali ada perintah lain. Jarak antara bahan tersebut dengan setiap bagian pembesian sekurang-kurangnya $5 \mathrm{~cm}$. Cara yang dibenarkan untuk mengikat bahan itu pada kedudukan yang benar adalah dengan kawat atau mengelas ke besi beton.

\subsubsection{Persiapan Permukaan yang Akan Dicor}

Sebelum adukan beton dicor, semua ruang-ruang yang akan diisi dengan beton dibersihkan dari kotoran-kotoran. Kemudian cetakan-cetakan dan pasangan-pasangan dinding yang akan berhubungan dengan beton dibasahi dengan air sampai jenuh. Permukaan tanah atau lantai kerja dibasahi dengan siraman air sebelum pengecoran. Permukaan tersebut harus tetap basah dengan penyiraman air terus menerus sampai tiba saat pengecoran. Bagaimanapun juga, permukaan tersebut harus bebas dari air yang tergenang, lumpur, dan kotoran-kotoran pada saat pengecoran beton.

\subsubsection{Sambungan Beton}

Bidang-bidang beton lama yang akan berhubungan erat dengan beton baru dan, bila perlu, dengan bidang-bidang akhir dari beton pada siar pelaksanaan dikasarkan dulu. Kemudian bidang-bidang tersebut dibersihkan dari segala kotoran dan benda-benda lepas, serta dibasahi dengan air sampai jenuh. Setelah permukaan disiapkan dengan persetujuan Pemberi Tugas/Pengawas Lapangan, sesaat sebelum beton yang baru akan dicor semua permukaan sambungan beton yang horizontal dilapisi atau disapu dengan spesi mortel dengan susunan yang sama seperti yang terdapat dalam betonnya. Lapisan spesi mortel tersebut disebar merata dan dikerjakan benar sampai mengisi ke dalam seluruh liku-liku permukaan beton lama yang tidak rata, sedapat mungkin dipergunakan sapu kawat untuk menyisipkan lapisan aduk tersebut ke dalam celah permukaan beton lama.

\subsubsection{Persiapan Pengecoran}

Beton tidak boleh dicor, bila seluruh pekerjaan bekisting, pekerjaan tulangan dan pekerjaan instalasi yang tertanam selesai dipasang dan persiapan seluruh permukaan tempat pengecoran. Seluruh permukaan bekisting dan bagian instalasi yang akan ditanam di dalam beton yang tertutup dengan kerak beton bekas pengecoran yang lalu, dibersihkan terhadap seluruh kerak beton tersebut sebelum beton di sekelilingnya atau beton yang berdekatan di cor.

\subsubsection{Penyingkiran Air}

Beton tidak boleh dicor sebelum semua genangan air yang memasuki tempat pengecoran tersebut dikeringkan dengan sebaik-baiknya. Beton tidak boleh dicor di dalam air. Selain itu, tidak dibenarkan membiarkan air mengalir di atas beton sebelum beton cukup umurnya dan mencapai pengerasan awal.

\subsubsection{Toleransi Kesalahan Pada Pelaksanaan Beton}

Beton mempunyai ukuran-ukuran dimensi lokasi dan bentuk yang tidak boleh melampaui toleransi berikut ini: posisi garis as dari penyelesaian bagian struktur pada semua titik $\pm 0,5 \mathrm{~cm}$ posisi yang seharusnya.

\subsubsection{Pembengkokan Besi Beton}

Pekerjaan pembengkokan besi dilaksanakan dengan teliti sesuai dengan ukuran yang tertera pada gambar.

Besi beton tidak boleh dibengkokkan atau diluruskan sedemikian rupa, sehingga rusak atau cacat, dan tidak diperbolehkan membengkokkan besi beton dengan cara pemanasan. Pembengkokan dilakukan dengan cara melingkari sebuah pasak berdiameter tidak kurang dari 5 kali diameter besi beton. Namun terdapat pengecualian untuk besi beton yang lebih besar dari 25 $\mathrm{mm}$ yaitu pasak yang digunakan tidak kurang dari 8 kali diameter. Semua pembesian mempunyai hak pada kedua ujungnya bilamana tidak ditentukan lain.

\subsubsection{Pemasangan Besi Tulangan}

Tahap pertama adalah pembersihan. Sebelum baja tulangan dipasang, besi beton harus bebas dari sisa logam, karatan, lemak dan lapisan yang dapat merusak atau mengurangi daya lekat besi dan beton.

Tahap kedua adalah pemasangan. Pembesian diatur dengan cermat sesuai dengan gambar dan diikat dengan kawat beton. Semua tulangan dipasang dengan posisi yang tepat. Tulangantulangan dipasang sedemikian rupa sehingga selama pengecoran tidak berubah tempatnya.

\subsection{Fondasi Tiang Pancang}

Struktur bangunan pada umumnya terdiri dari struktur bawah (lower structure) dan struktur atas (upper structure). Struktur bawah (lower structure) yang dimaksud adalah fondasi dan struktur bangunan yang berada di bawah permukaan tanah, sedangkan struktur atas (upper structure) adalah struktur bangunan yang berada di atas 
permukaan tanah seperti kolom, balok, plat, dan tangga. Setiap komponen tersebut memiliki fungsi yang berbeda-beda di dalam sebuah struktur.

Suatu bangunan gedung beton bertulang yang berlantai banyak sangat rawan terhadap keruntuhan jika tidak direncanakan dengan baik. Oleh karena itu, diperlukan suatu perencanaan struktur yang tepat dan teliti agar dapat memenuhi kriteria kekuatan (strenght), kenyamanan (serviceability), keselamatan (safety), dan umur rencana bangunan (durability).

Beban-beban yang bekerja pada struktur seperti beban mati (dead load), beban hidup (live load), beban gempa (earthquake), dan beban angin (wind load) menjadi bahan perhitungan awal dalam perencanaan struktur untuk mendapatkan besar dan arah gaya-gaya yang bekerja pada setiap komponen struktur. Kemudian dapat dilakukan analisis struktur untuk mengetahui besarnya kapasitas penampang dan tulangan yang dibutuhkan oleh masing-masing struktur (Gideon dan Takim, 1993).

Perencanaan struktur atas mengacu pada peraturan atau pedoman standar yang mengatur perencanaan dan pelaksanaan bangunan beton bertulang, yaitu Persyaratan Beton Struktural untuk Bangunan Gedung nomor: SNI 2847:2013, Tata Cara Ketahanan Gempa untuk Struktur Bangunan Gedung dan Non Gedung nomor: SNI 1726:2012, dan Spesifikasi untuk Bangunan Gedung Baja Struktural nomor: SNI 1729:2015 (SNI, 2012; SNI, 2013; SNI, 2015)

Dalam perhitungan struktur bawah fondasi struktur tangki CSTR ada beberapa hal yang perlu diperhatikan seperti:

3.3.1. Peraturan dan Standard yang Digunakan Perhitungan desain disesuaikan dengan mengikuti peraturan, spesifikasi, dan standar gambar sebagaimana berikut:

- Peraturan dan Standar Indonesia

SNI-03-1726-2012: Tata Cara Perencanaan Ketahanan Gempa untuk Bangunan Gedung (SNI. 2013)

- Peraturan dan Standar Amerika

$\mathrm{ACl}$ 318: Building Code Requirements for Structural Concrete.

ACl 315: Standard Practice for Detailing Reinforced Concrete Structures.

ASCE 7: Minimum Design Loads for Buildings and Other Structures.

ASTM: American Society for Testing and Materials (ASTM, 2013)

\subsubsection{Material Utama}

Klasifikasi dan properties engineering dari material utama yang digunakan untuk fondasi tangki ini adalah sebagai berikut:

Beton

$$
\begin{aligned}
& \text { Mutu Beton }\left(F c^{\prime}=250 \mathrm{~kg} / \mathrm{cm}^{2}\right) \\
& \text { Berat Volume Beton }\left(\mathrm{Yc}=2400 \mathrm{~kg} / \mathrm{m}^{3}\right) \\
& \text { Kuat Leleh Tulangan }\left(\mathrm{Fy}=4200 \mathrm{~kg} / \mathrm{cm}^{2}\right)
\end{aligned}
$$

\author{
Berat Volume Tanah $(\mathrm{ys}=1800 \mathrm{~kg} / \mathrm{m})$ \\ Anchor Bolt (ASTMA36) \\ Tiang Pancang (JIS A5335 CLASSA)
}

\subsubsection{Konsep Desain}

Beban akibat berat fondasi dan isinya disalurkan ke tiang pancang dan total dari berat ini tidak boleh melebihi kapasitas daya dukung ijin dari tiang pancang. Kombinasi beban tidak berfaktor digunakan untuk cek kapasitas tiang pancang, sedangkan kombinasi beban berfaktor digunakan untuk desain penulangan.

\subsubsection{Data Tangki}

Berdasarkan rencana desain tangki CSTR seperti terlihat pada Gambar 3, memiliki spesifikasi:

$$
\begin{aligned}
& \mathrm{I} . \mathrm{D}=16800 \mathrm{~mm} \\
& \text { C. } 0 . \mathrm{G}=4500 \mathrm{~mm} \\
& \mathrm{H} 1=9000 \mathrm{~mm} \\
& \mathrm{Ht}=550 \mathrm{~mm}
\end{aligned}
$$

\subsubsection{Rencana Berat Tangki CSTR}

- Berat Kosong (berdasarkan data sheet peralatan)

Berat mati equipment saat kondisi erection $E(E)=81,3$ ton.

- Berat Operasi (Berat Kosong + Fluida)

Berat total equipment saat kondisi operasi $\mathrm{E}(\mathrm{O})=1796.1$ ton .

- $\quad$ Berat Test (Berat Operasi × FK(1.2))

- Berat total tangki saat kondisi tes $\mathrm{E}(\mathrm{T})=2155,4$ ton.

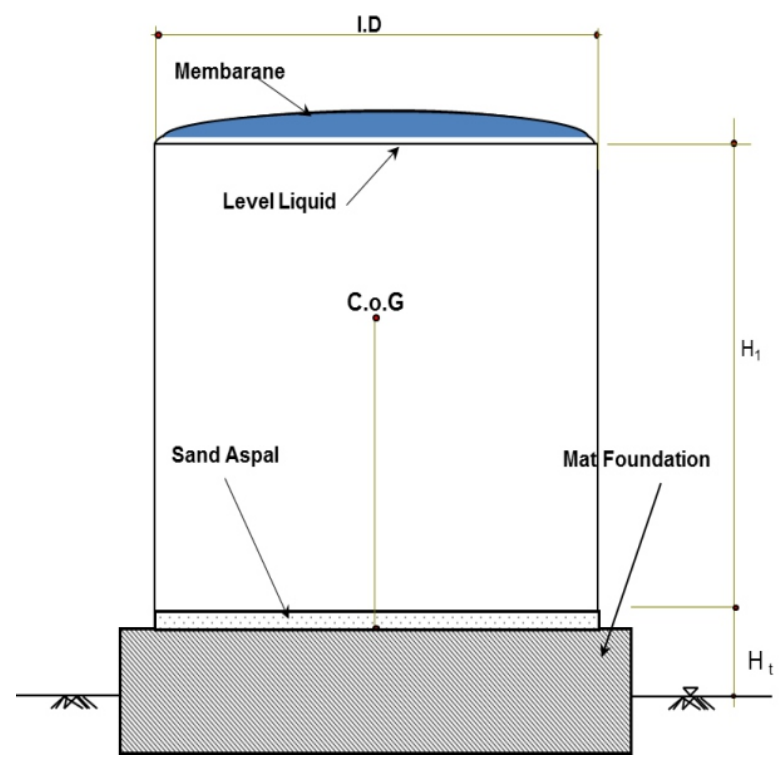

Gambar 3. Desain Fondasi Tangki CSTR

\subsubsection{Data Tanah}

Pengambilan data tanah di area Biogas Pome dilakukan dengan 5 titik sondir dan 2 titik bore hole dimana hasil data tanah dapat dilihat dalam Tabel 1 dan Gambar 4. 

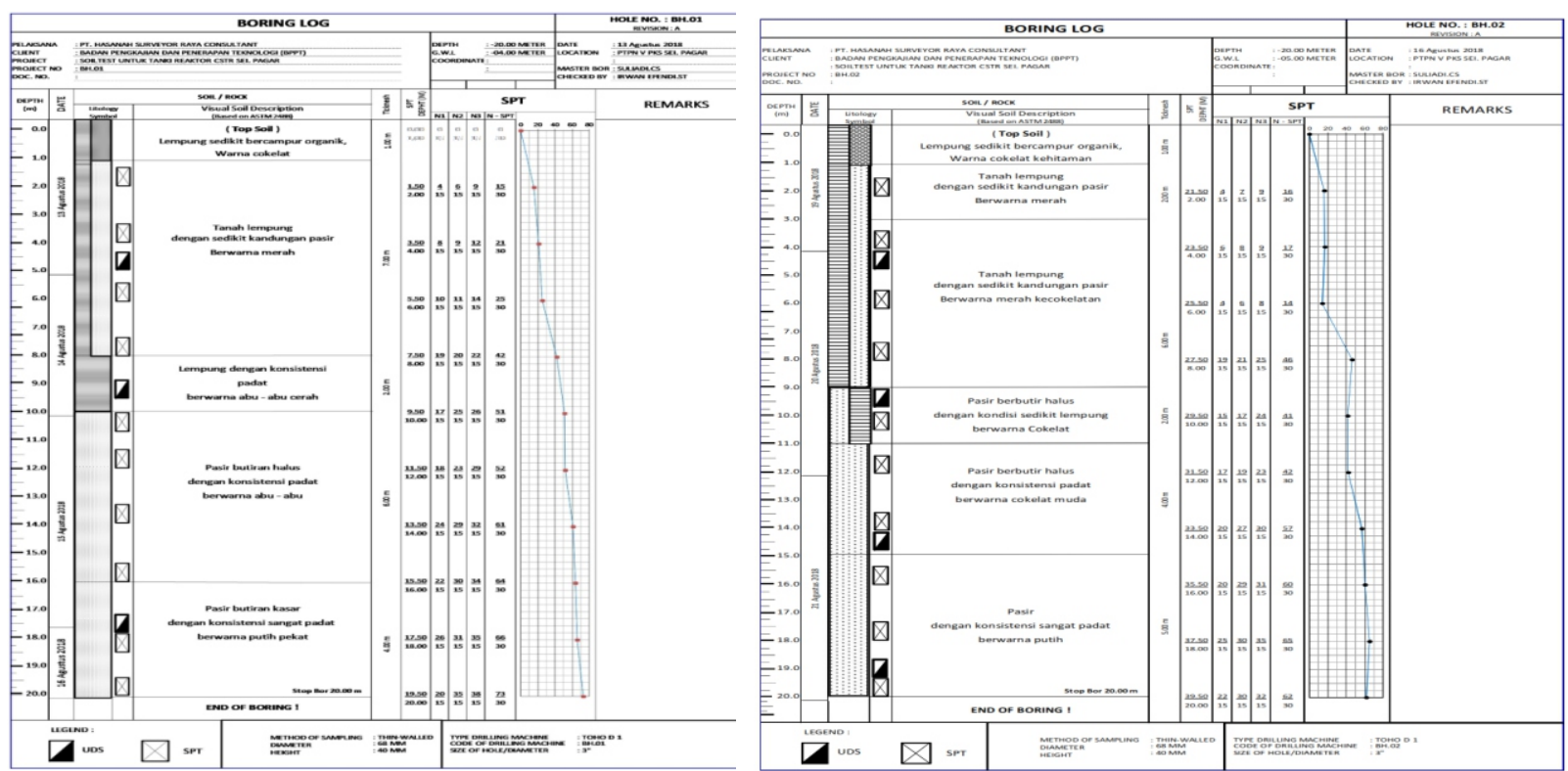

Gambar 4. Data Bore Hole

Tabel 1. Data Sondir

\begin{tabular}{|c|c|c|c|c|c|c|c|}
\hline \multirow{3}{*}{$\begin{array}{c}\text { Titik } \\
\text { Sondir }\end{array}$} & \multirow{3}{*}{$\begin{array}{c}\text { Kedalaman } \\
\text { Maximum }\end{array}$} & \multicolumn{2}{|c|}{$\begin{array}{c}\text { PENETROMETER } \\
\left(\mathrm{Kg} / \mathrm{Cm}^{2}\right)\end{array}$} & \multicolumn{2}{|c|}{$\begin{array}{l}\text { RESISTANCE } \\
\left(\mathrm{Kg} / \mathrm{Cm}^{2}\right)\end{array}$} & \multirow{3}{*}{$\begin{array}{l}\text { T. FRICTION } \\
\text { COMULATIF } \\
\left(\mathrm{Kg} / \mathrm{Cm}^{2}\right)\end{array}$} & \multirow{2}{*}{$\begin{array}{c}\text { RATIO } \\
\text { (Fs/qc) } \\
\text { (\%) }\end{array}$} \\
\hline & & First & Second & CONE & FRICTION & & \\
\hline & & M1 & M2 & qc & Fs & & \\
\hline S.1 & 9,20 & 220 & 225 & 220 & 0,5 & 724,0 & 0,23 \\
\hline S.2 & 8,80 & 210 & 215 & 210 & 0,5 & 746,0 & 0,24 \\
\hline S. 3 & 12,40 & 210 & 215 & 210 & 0,5 & 1510,0 & 0,24 \\
\hline S.4 & 12,40 & 215 & 220 & 215 & 0,5 & 1370,0 & 0,23 \\
\hline S.5 & 11,20 & 200 & 205 & 200 & 0,5 & 1134,0 & 0,25 \\
\hline
\end{tabular}

Nilai tekanan konus $\mathrm{q}_{\mathrm{c}}>200 \mathrm{~kg} / \mathrm{cm}^{2}$ diperoleh pada kedalaman $9,20 \mathrm{~m}$ s.d. $12,40 \mathrm{~m}$, yang merupakan indikasi adanya tanah keras.

\section{Hasil Standard Penetration Test (SPT)}

- Indikasi bearing layer (lapisan dukung) berada pada kedalaman 10-12,50 m dibawah muka tanah, dimana lapisan tanah mempunyai nilai N-SPT mendekati nilai 45 s.d. 50.

- Pemancangan perlu dilakukan sampai kedalaman 12,00 m dibawah muka tanah.

\footnotetext{
Asumsi Pembebanan

Beban Angin

Kecepatan Angin Dasar (V)

$\mathrm{V}=35 \mathrm{~m} / \mathrm{s}=126 \mathrm{k} \mathrm{m} / \mathrm{h}$

$=78.26 \mathrm{mph}$

$\approx \quad 80 \mathrm{mph}$

Desain Beban Angin

Perhitungan beban angin mengacu pada ASCE

7 , yang dihitung berdasarkan formula berikut:

$\mathrm{qz}=0.613 \times \mathrm{Kz} \times \mathrm{Kzt} \times \mathrm{Kd} \times \mathrm{V} 2 \times \mathrm{I}$

dimana:

$\mathrm{qz}=$ Velocity pressure dievaluasi pada ketinggian $z$ di atas tanah

$\mathrm{Kz}=$ koefisien velocity pressure

$\mathrm{Kzt}=$ faktor topografi $=1$

$\mathrm{Kd}=$ faktor untuk Wind directional $=0.95$ untuk chimney, tangki dan struktur sejenis
}

$\mathrm{V}=$ Kecepatan angin dasar $=28 \mathrm{~m} / \mathrm{s}$

$\mathrm{I}=$ Faktor keutamaan $=1,15$ (Category III)
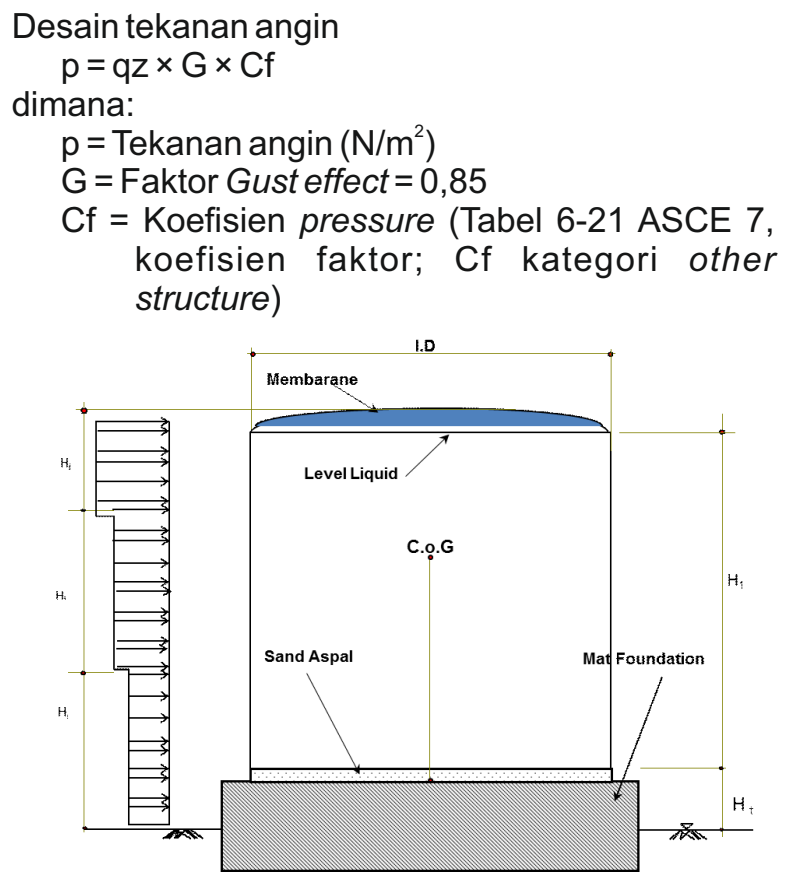

Gambar 5. Asumsi Perhitungan

Berdasarkan data berat dan data angin bisa disimpulkan seperti tertera pada Tabel 2 .

Tabel 2. Data GayaAngin

\begin{tabular}{|c|c|c|c|c|c|c|c|c|c|c|c|c|c|}
\hline $\begin{array}{c}\text { Elevasi } \\
\mathrm{m}\end{array}$ & Kz & Kzt & $\mathrm{Kd}$ & $\begin{array}{c}\underset{(m / s)}{V} \\
\text { D. }\end{array}$ & I & $\begin{array}{c}\text { qz } \\
(\mathrm{N} / \mathrm{m} 2)\end{array}$ & G & $\mathrm{Cf}$ & $\begin{array}{c}p \\
(\mathrm{~kg} / \mathrm{m} 2)\end{array}$ & $B(m)$ & $H(m)$ & $\begin{array}{c}1.2 \times A f \\
(\mathrm{~m} 2)\end{array}$ & $\begin{array}{c}F(\mathrm{~kg}) \\
(\mathrm{P} \times 1.2 \times \mathrm{Af})\end{array}$ \\
\hline $0.0 \sim 4.6$ & 0,85 & 0,04 & 0,95 & 35 & 1,15 & $\begin{array}{l}697,3 \\
\end{array}$ & 0,85 & 0,75 & 45,4 & $\begin{array}{l}16,80 \\
\end{array}$ & 4,60 & 92,40 & $4.206,68$ \\
\hline $4.6 \sim 6.1$ & 0,90 & 0,04 & 0,95 & 35 & 1,15 & 738,3 & 0,85 & 0,75 & 48,0 & 16,80 & 1,50 & 30,24 & $1.452,43$ \\
\hline $6.1 \sim 7.62$ & 0,94 & 0,04 & 0,95 & 35 & 1,15 & 771,2 & 0,85 & 0,75 & 50,2 & 16,80 & 1,50 & 30,24 & $1.516,99$ \\
\hline $7.6 \sim 9.1$ & 0,98 & 0,04 & 0,95 & 35 & 1,15 & 804,0 & 0,85 & 0,75 & 52,3 & 16,80 & 1,50 & 30,24 & $\frac{1.581,54}{7174}$ \\
\hline
\end{tabular}




\subsection{Perencanaan Perhitungan Fondasi Tiang Pancang}

Perencanaan perhitungan pondasi tiang pancang sebagaimana terlihat pada skema berikut.

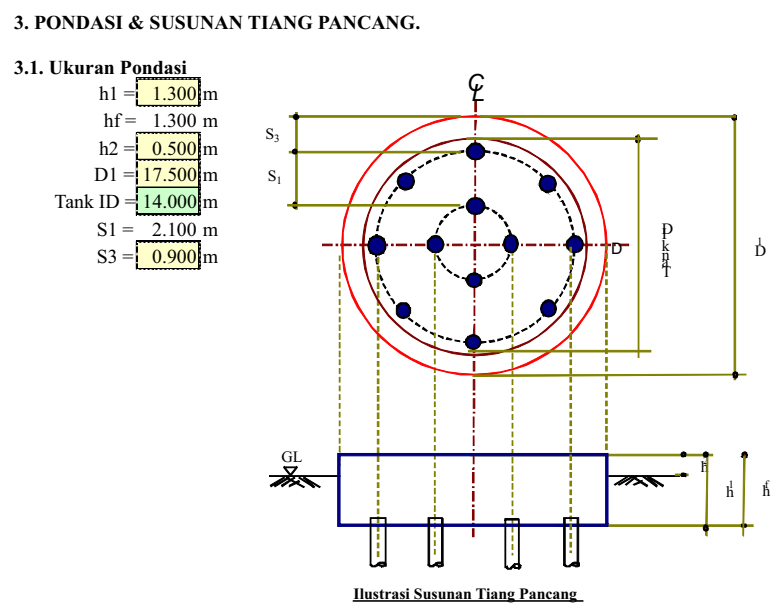

Gambar 6. Asumsi Perhitungan

\section{Jumlah Fondasi Tiang Pancang}

- Diameter pile : $\varnothing$ \% $=0.6 \mathrm{~m}$

- Panjang pile : $\mathrm{L}=12 \mathrm{~m}$

- Jarak antar PCD, S1 = n x D, n 3.5

$$
\begin{array}{r}
\text { - Jumlah PCD }(n)=4 \\
\text { - } \text { PCD }_{1}=15.70 \mathrm{~m}
\end{array}
$$

- Jumlah pile pada PCD. $\left(\mathrm{n}_{1}\right)=14$ pcs

$$
\text { - } \mathrm{PCD}_{2}=11.50 \mathrm{~m}
$$

- Jumlah Pile pada PCD : $\left(\mathrm{n}_{2}\right)=10$ pcs

$$
\text { - } \mathrm{PCD}_{3}=7.30 \mathrm{~m}
$$

- Number of piles in PCD: $\left(\mathrm{n}_{3}\right)=6$ pcs

$$
\text { - } \mathrm{PCD}_{4}=3.10 \mathrm{~m}
$$

- Number of piles in PCD: $\left(\mathrm{n}_{4}\right)=2.00$ pcs

$$
\text { - Jumlah total piles } \text { (p) }=32 \text { pcs }
$$

\section{Gambar 7. Asumsi Jumlah Pile}

Direncanakan diameter pile $0,6 \mathrm{~cm}$ dengan panjang $12 \mathrm{~m}$.

\section{Cek Jumlah Fondasi Tiang Pancang}

\section{Beban Kombinasi Tidak Berfaktor di Bawah Footing}
1. Kosong:
$\mathrm{D}+\mathrm{E}(\mathrm{E})$
2. Kosong + Angin :
$\mathrm{D}+\mathrm{E}(\mathrm{E})+\mathrm{W}$
3. Normal / Operasi
$\mathrm{D}+\mathrm{E}(\mathrm{O})$
4. Normal / Operasi + Angin
$\mathrm{D}+\mathrm{E}(\mathrm{O})+\mathrm{W}$
5. Normal / Operasi + Gempa
$\mathrm{D}+\mathrm{E}(\mathrm{O})+\mathrm{V}$
6. Test
7. Test + Angin :
$\mathrm{D}+\mathrm{E}(\mathrm{T})$
$\mathrm{D}+\mathrm{E}(\mathrm{T})+0.25 \mathrm{~W}$

where : $\quad \mathrm{D}=$ Beban Mati $=$ Berat Pondasi (Wf)

$$
E(O)=\text { Beban Operasi }
$$

$\mathrm{W}=$ Beban Angin

$\mathrm{V}=$ Beban Gempa

$\mathrm{E}(\mathrm{E})=$ Kosong $/$ Erection

$\mathrm{E}(\mathrm{T})=$ Beban Test
Dengan memperhitungkan beban kombinasi di atas, dimana ada 7 kombinasi pembebanan untuk mendapatkan reaksi gaya maksimum maka didapatkan reaksi gaya seperti Tabel 3.

Tabel 3. Cek Reaksi Gaya

\begin{tabular}{|c|c|c|c|}
\hline Kombinasi Pembebanan & $\begin{array}{c}\mathrm{V} \\
\text { (ton) }\end{array}$ & $\begin{array}{c}\mathrm{H} \\
\text { (ton) }\end{array}$ & $\begin{array}{c}\mathrm{M} \\
\text { (tm) }\end{array}$ \\
\hline $\mathrm{D}+\mathrm{E}(\mathrm{E})$ & & & \\
\hline $\mathrm{D}+\mathrm{E}(\mathrm{E})+\mathrm{W}$ & 846.25 & 0.00 & 0.00 \\
\hline $\mathrm{D}+\mathrm{E}(\mathrm{O})$ & 846.25 & 11.68 & 111.57 \\
\hline $\mathrm{D}+\mathrm{E}(\mathrm{O})+\mathrm{W}$ & 2654.47 & 0.00 & 0.00 \\
\hline $\mathrm{D}+\mathrm{E}(\mathrm{O})+\mathrm{V}$ & 2654.47 & 11.68 & 111.57 \\
\hline $\mathrm{D}+\mathrm{E}(\mathrm{T})$ & 2654.47 & 542.57 & 3816.38 \\
\hline $\mathrm{D}+\mathrm{E}(\mathrm{T})+0.25 \mathrm{~W}$ & 3035.27 & 0.00 & 0.00 \\
\hline & 3035.27 & 2.92 & 27.89 \\
\hline & & & \\
\hline
\end{tabular}

\begin{tabular}{|c|c|c|c|c|c|c|c|c|}
\hline \multirow{2}{*}{ 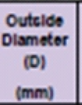 } & \multirow{2}{*}{$\begin{array}{l}\text { Wall } \\
\text { Thloknoce } \\
\text { (t) } \\
(\mathrm{mm})\end{array}$} & \multirow[b]{2}{*}{ Claece } & \multirow{2}{*}{$\begin{array}{l}\text { Croces } \\
\text { sootion } \\
\text { (om2) }\end{array}$} & \multirow{2}{*}{$\begin{array}{l}\text { Unit } \\
\text { Wolont } \\
\text { aglm) }\end{array}$} & \multirow{2}{*}{$\begin{array}{c}\text { Longth } \\
(\mathrm{L}) \\
(\mathrm{m}) \\
\end{array}$} & \multicolumn{2}{|c|}{ Bending Momont } & \multirow{2}{*}{$\begin{array}{l}\text { Allowable } \\
\text { Axtal Losd } \\
\text { (Ton) }\end{array}$} \\
\hline & & & & & & $\begin{array}{c}\text { Craok } \\
\text { (Ton.m) }\end{array}$ & $\begin{array}{l}\text { Utilimato } \\
\text { (Ton.m) }\end{array}$ & \\
\hline 300 & 60 & $\begin{array}{l}\mathrm{N} \\
\mathrm{N} \\
\mathrm{B} \\
\mathrm{C} \\
\end{array}$ & 452 & 113 & $6 \cdot 13$ & $\begin{array}{l}250 \\
300 \\
350 \\
400 \\
\end{array}$ & $\begin{array}{l}3.75 \\
4.50 \\
6.30 \\
8.00 \\
\end{array}$ & $\begin{array}{l}72.60 \\
70.75 \\
67.50 \\
65.40 \\
\end{array}$ \\
\hline 350 & 65 & $\begin{array}{l}\mathrm{A} \\
\mathrm{N} \\
\mathrm{B} \\
\mathrm{C} \\
\end{array}$ & 582 & 145 & $6 \cdot 15$ & $\begin{array}{l}350 \\
420 \\
500 \\
600 \\
\end{array}$ & $\begin{array}{l}5.25 \\
6.30 \\
9.00 \\
12.00 \\
\end{array}$ & $\begin{array}{l}93.10 \\
89.50 \\
86.40 \\
85.00 \\
\end{array}$ \\
\hline 400 & 75 & $\begin{array}{l}\mathrm{N}^{2} \\
\mathrm{~N} \\
\mathrm{~B} \\
\mathrm{C}\end{array}$ & 766 & 191 & $6 \cdot 16$ & $\begin{array}{l}550 \\
650 \\
750 \\
900 \\
\end{array}$ & $\begin{array}{l}8.25 \\
9.75 \\
13.50 \\
18.00 \\
\end{array}$ & $\begin{array}{l}121.10 \\
117.60 \\
114.40 \\
111.50 \\
\end{array}$ \\
\hline 450 & 80 & $\begin{array}{l}A 1 \\
A_{2} \\
N_{3} \\
B \\
C \\
\end{array}$ & 930 & 232 & $6 \cdot 16$ & $\begin{array}{l}7.50 \\
8.50 \\
10.00 \\
11.00 \\
12.50 \\
\end{array}$ & $\begin{array}{l}11.25 \\
12.75 \\
15.00 \\
19.80 \\
25.00 \\
\end{array}$ & $\begin{array}{l}149.50 \\
145.80 \\
143.80 \\
139.10 \\
134.90 \\
\end{array}$ \\
\hline 500 & 90 & $\begin{array}{l}A_{1} \\
N_{2} \\
N_{3} \\
B \\
C\end{array}$ & 1159 & 290 & $6 \cdot 16$ & $\begin{array}{l}10.50 \\
12.50 \\
14.00 \\
15.00 \\
17.00\end{array}$ & $\begin{array}{l}15.75 \\
18.75 \\
21.00 \\
27.00 \\
34.00\end{array}$ & $\begin{array}{l}165.30 \\
161.70 \\
179.20 \\
174.90 \\
169 . \infty\end{array}$ \\
\hline 600 & 100 & $\begin{array}{l}\mathrm{Al}_{1} \\
\mathrm{~N}_{2} \\
\mathrm{~N}_{3} \\
\mathrm{~B} \\
\mathrm{C}\end{array}$ & 1571 & 393 & $6 \cdot 16$ & $\begin{array}{l}1700 \\
1900 \\
2200 \\
2500 \\
2900\end{array}$ & $\begin{array}{l}25.50 \\
29.50 \\
33.00 \\
45.00 \\
59.00\end{array}$ & $\begin{array}{l}252.70 \\
249.00 \\
243.20 \\
239.30 \\
229.50 \\
\end{array}$ \\
\hline
\end{tabular}

Dari Tabel 3 tersebut, gaya reaksi vertikal terbesar akibat beban tes+angin adalah sebesar 3055.27 ton, sedangkan reaksi gaya horizontal terbesar adalah 542.57 ton akibat beban operasi+angin.

Tabel 4. Data Vendor Pile

Berdasarkan analisis yang dicantumkan pada

\begin{tabular}{|c|c|}
\hline Fondasi Tapak & Fondasi Tiang Pancang \\
\hline 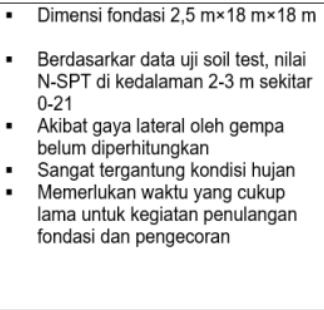 & $\begin{array}{l}\text { - Kedalaman tiang pancang } 12 \mathrm{~m} \text {, ketebalan } \\
\text { pile cap } 1 \mathrm{~m} \text {, dan diameter } 60 \mathrm{~cm} \\
\text { - Berdasarkan data uji soil test, nilai } \mathrm{N} \text { yang di } \\
\text { rekomendasikan N-SPT } 45-50 \text { dikedalaman } \\
17-18 \mathrm{~m} \\
\text { - Sudah dianalisis oleh WP } 2.6 \text { akibat gaya } \\
\text { lateral } \\
\text { Bisa dikerjakan dengan kondisi hujan ringan } \\
\text { Butuh waktu } 10 \text { hari untuk pemancangan dan } \\
14 \text { hari untuk kegiatan penulangan dan } \\
\text { Laporan WP } 2.6 \text { Desain Struktur Sipil Sistim } \\
\text { Tangki PLT Biogas POME, BTBRD-BPPT } \\
\text { - pengecoran pile cap }\end{array}$ \\
\hline
\end{tabular}
Tabel 4, dipilih fondasi berdiameter $60 \mathrm{~cm}$ type B dengan nilai Allowable Axial Load sebesar 238,30 ton. Maka kekuatan fondasi pile adalah sebesar $238,30 \times 32 \times 0,65$ atau 4.956,64 ton.

Tabel 5. Perbandingan fondasi tapak dan fondasi tiang pancang 


\section{KESIMPULAN}

Dari kajian pemilihan fondasi tangki reaktor, disimpulkan beberapa hal sebagai berikut:

- Pemakaian fondasi dangkal sangat tidak memungkinkan karena rekomendasi dari data soil test dimana tanah keras di kedalaman 1012,5 m, di kedalaman 0-5 m masih N-SPT 021, dan perhitungan fondasi belum bisa menahan gaya lateral akibat gempa.

- Pemilihan tiang pancang didasari atas dasar perhitungan dimana gaya vertikal dengan nilai 3035,37 ton, sedangkan beban yang harus diterima pada gaya horizontal yang bekerja sekitar 542,57 ton.

- Pemilihan fondasi tiang pancang sebagai pilihan yang tepat karena faktor waktu, biaya yang lebih murah, dan waktu pengerjaan yang cepat.

dome.

\section{DAFTAR PUSTAKA}

AISC-ASD 9th. Tahun. Specification for the Design, Fabrication and Erection of Structure Steel for Building, Allowable Stress Design

Anonim. 2017.Outlook Kelapa Sawit 2017
Anonim. 2017. Permen ESDM 50 Tahun 2017 Pemanfaatan Sumber Energi Terbarukan Untuk Penyediaan Tenaga Listrik

ASCE 7-05. Tahun. Minimum Design Loads for Buildings and other structures ACI 318-05. Building Code Requirements for Reinforced Concrete ACI 315. Standard Practice for Detailing Concrete Structure

ASME. Tahun. Section 8 Div.1: Pressure Vessel

ASTM. 2013. American Society for Testing and Materials

Gideon dan Takim, 1993).

PERMEN ESDM No. 50/2017, 2017

Rahayu, A. S. dkk. 2015. Buku Panduan Konversi POME Menjadi Biogas Pengembangan Proyek di Indonesia, 2015.

SNI 1726: 2012. Tata Cara Perencanaan Ketahanan Gempa untuk Struktur Bangunan Gedung dan Non Gedung

SNI 1727: 2013. Beban Minimum untuk Perancangan Bangunan Gedung dan Struktur Lain

SNI 2847: 2013. Persyaratan Beton Struktural untuk Bangunan Gedung

SNI 1729: 2015. Spesifikasi Untuk Bangunan Gedung Baja Struktural 